\title{
Settlement Of Crassostrea Ariakensis Larvae: Effects Of Substrate, Biofilms, Sediment And Adult Chemical Cues
}

\author{
Mario N. Tamburri \\ Mark W. Luckenbach \\ Virginia Institute of Marine Science \\ Denise L. Brietburg \\ Stephanie M. Bonniwell \\ Virginia Institute of Marine Science
}

Follow this and additional works at: https://scholarworks.wm.edu/vimsarticles

Part of the Aquaculture and Fisheries Commons

\section{Recommended Citation}

Tamburri, Mario N.; Luckenbach, Mark W.; Brietburg, Denise L.; and Bonniwell, Stephanie M., Settlement Of Crassostrea Ariakensis Larvae: Effects Of Substrate, Biofilms, Sediment And Adult Chemical Cues (2008). Journal of Shellfish Research, 27(3), 601-608.

https://scholarworks.wm.edu/vimsarticles/1372 


\title{
SETTLEMENT OF CRASSOSTREA ARIAKENSIS LARVAE: EFFECTS OF SUBSTRATE, BIOFILMS, SEDIMENT AND ADULT CHEMICAL CUES
}

\author{
MARIO N. TAMBURRI, ${ }^{1 *}$ MARK W. LUCKENBACH, ${ }^{2}$ DENISE L. BREITBURG ${ }^{3}$ \\ AND STEPHANIE M. BONNIWELL ${ }^{2}$ \\ ${ }^{1}$ Chesapeake Biological Laboratory, University of Maryland Center for Environmental Science, One \\ Williams Street, Solomons, Maryland 20688; ${ }^{2}$ Virginia Institute of Marine Science, Eastern Shore \\ Laboratory, College of William and Mary P.O. Box 350, Wachapreague, Virginia 23480 \\ ${ }^{3}$ Smithsonian Environmental Research Center, P.O. Box 28, Edgewater, Maryland 21037
}

\begin{abstract}
The Suminoe oyster (Crassostrea ariakensis) is being considered for introduction into the Chesapeake Bay. However, our current understanding of the biology and ecology of $C$. ariakensis is insufficient to predict whether an introduction will be successful, provide desired benefits, or have adverse impacts. Behavior of native Eastern oyster (C. virginica) pediveligers has been studied for many years and it is well established that they use a variety of habitat characteristics when selecting a site for colonization. Perhaps the most important of these are chemical cues emitted by adult conspecifics, which can lead to gregarious larval settlement and dense, persistent reef communities. Conversely, almost nothing is known about the mechanisms that regulate larval settlement and metamorphosis for $C$. ariakensis or how pediveligers might respond to conditions found in Chesapeake Bay. In a comparative study with $C$. virginica, we examined how environmental factors such as substrate type, natural biofilms, sediment and waterborne chemical cues influence larval settlement for two C. ariakensis strains ("south China" and "west coast"). Our results demonstrate many similarities but also potentially important differences. Both species and strains of larvae greatly prefer natural substrates (e.g., shell) covered with biofilms for colonization but the west coast strain of $C$. ariakensis exhibited greater attachment onto manmade substrates (e.g., fiberglass) than C. virginica. Waterborne chemical cues emitted by adult oysters were also found to enhance substrate attachment for all larval forms but cues do not appear to be species specific. These results provide critical insight to the ability of $C$. ariakensis larvae to identify and colonize suitable substrates in the Chesapeake Bay, which will have a large impact on recruitment success and their ability to establish self-sustaining populations.
\end{abstract}

KEY WORDS: larval behavior, settlement, substrate preference, chemical cues, Suminoe oyster, Crassostrea ariakensis

\section{INTRODUCTION}

The Eastern oyster, Crassostrea virginica (Gmelin 1791), has historically supported a culturally and economically important fishery along the Atlantic and Gulf of Mexico coasts of the United States (Kent 1988, Mackenzie \& Burrell 1997) and served as an important component of many estuarine ecosystems. Reefs built by oysters provide structure and habitat for a diverse assemblage of organisms, while consuming phytoplankton and reducing the accumulation of organic matter in the water column (Newell 1988, Lenihan \& Grabowski 1998, Coen \& Luckenbach 2000). Crassostrea virginica populations in the Chesapeake Bay are, however, at historic low levels as a result of several factors such as heavy harvesting pressure, habitat degradation, and high mortality caused by diseases (e.g., Homer et al. 1996, Ford \& Ashton-Alcox 1998, Kirby \& Miller 2005).

In response to this decline in native Eastern oysters, the states of Maryland and Virginia are considering introducing the Asian Suminoe oyster (C. ariakensis [Fujita 1913]) into the tidal waters of the Chesapeake Bay with the goal of establishing a naturalized, reproducing, and self-sustaining population of this nonnative species (see review by National Research Council 2004). However, neither the potential risks nor the potential benefits of introducing $C$. ariakensis to this region are adequately known. The current understanding of the biology and ecology of $C$. ariakensis is insufficient to predict whether an introduction will provide desired benefits or have substantial

*Corresponding author. E-mail: tamburri@cbl.umces.edu adverse impacts within the Chesapeake Bay or other Atlantic Coast estuaries over the short- or long-term.

To address this lack of knowledge, priority areas for research have been identified in the National Research Council (NRC) report on Nonnative Oysters in the Chesapeake Bay (NRC 2004) and the Scientific and Technical Advisory Committee (STAC) of the Chesapeake Bay program report on identifying and prioritizing research required to evaluate ecological risks and benefits of introducing diploid Crassostrea ariakensis to restore oysters to Chesapeake Bay (STAC 2004). Many of the recommendations and priorities focus on the larval biology and ecology of $C$. ariakensis. For example, the ability to answer the basic question of whether $C$. ariakensis can survive and reproduce in Chesapeake Bay is dependent in large part on understanding their larval behavior and settlement in response to environmental conditions found in the mainstem Bay and other tidal waters of Maryland and Virginia.

Many benthic organisms produce planktonic larvae whose dispersal and recruitment to benthic sites affects population dynamics and community structure (Olafsson et al. 1994, Palmer et al. 1996). The first step in larval recruitment is settlement (movement onto and attachment of a larva to the substratum). Although settlement and postsettlement events affect recruitment, there are many cases in which temporal and spatial patterns in recruitment are caused by larval settlement (review: Roughgarden et al. 1991, Rothlisberg \& Church 1994). Habitat selection during settlement for sessile benthic animals, such as oysters, is of particular significance because there is essentially no chance of relocation after metamorphosis onto a substrate. 
It has been well established that $C$. virginica pediveligers can use a variety of habitat characteristics when selecting a site for colonization. For example, bacterial films and other organic factors that characterize a suitable substrate are involved in triggering behavioral changes at settlement (Veitch \& Hidu 1971, Fitt et al. 1989). Perhaps the most important of such chemical cues are emitted by adults of the same species. It has been shown that for $C$. virginica and $C$. gigas, chemical signals exuded by adult conspecifics induce larval settlement from the water column (Tamburri et al. 1992, Turner et al. 1994, Zimmer-Faust \& Tamburri 1994, Tamburri et al. 2007).

Larval behavioral responses to chemical signals released by adults of the same species often lead to dense, persistent aggregations of conspecifics (Hidu 1969, Pawlik 1992), such as oyster reefs (Bayne 1969, Tamburri et al. 1996, Tamburri et al. 2007). This gregariousness presumably increases postmetamorphic survival (Buss 1981, Highsmith 1982, Sebens 1983), and/or mating success (Pennington 1985, Denny \& Shibata 1989, Levitan 1991). For oysters that are sessile broadcast spawners, neighboring conspecifics are obviously required to assure successful reproduction.

It is also well established that $C$. virginica requires sedimentfree, hard substrate for metamorphosis. However, high sediment loads have become a common problem in the Chesapeake Bay and excessive siltation levels on reefs has been shown to impair habitat quantity and quality for settling $C$. virginica larvae and newly attached juveniles (Bahr 1976, Seliger \& Boggs 1988). The preferred substrate for $C$. virginica is oyster shell, but pediveliger larvae begin the complex process of cementing to the substrate in response to other hard surfaces, such as rocks, pilings, etc. as well (Kennedy 1996).

It is unknown, however, what benthic habitats are most suitable for $C$. ariakensis and which substrate types/characteristics will trigger settlement and metamorphosis. There are also uncertainties about the reef-building characteristics of $C$. ariakensis in different regions where it naturally occurs (NRC 2004). Whereas known as a "reef-builder," there are observations of this species living as single individuals in areas where soft sediment predominates (Luckenbach, personal observations).

This study was designed to determine how the substrate preferences of $C$. ariakensis at the time of settlement differ from or resembles those of $C$. virginica and ultimately how these traits will impact recruitment, the likelihood of successful introduction into the Chesapeake Bay, and the potential for becoming a fouling nuisance species. Specifically, laboratory experiments were conducted to examine the substrate preferences of C. virginica and $C$. ariakensis larvae and their response to waterborne chemical cues. For this study, "settlement" is defined as contact with and attachment to a surface, including complete metamorphosis into spat.

\section{MATERIALS AND METHODS}

\section{Larval Culture}

All spawning, larval rearing and experiments were carried out in a quarantined laboratory at the Virginia Institute of Marine Science's Eastern Shore Laboratory in Wachapreague, VA. Experiments were conducted using larvae spawned from wild $C$. virginica collected in the vicinity of the laboratory and two strains of $C$. ariakensis: one strain, termed "west coast $C$. ariakensis" (and henceforth termed "WCA"), is derived from stocks imported into the United States west coast from Japan in the 1970s (Breese \& Malouf 1977); the other strain, termed "south China $C$. ariakensis" (henceforth "SCA"), is an F3 generation from stocks imported from southern China. All effluent water from the laboratory was chlorinated $(0.5 \mathrm{~mL} 5 \%$ $\mathrm{Na}$ hypochlorite $\mathrm{L}^{-1}$ of effluent) and dechlorinated $(0.167 \mathrm{~g} \mathrm{Na}$ thiosulfate $\mathrm{mL}^{-1}$ of $\mathrm{Na}$ hypochlorite) prior to discharge to ensure that no escape of gametes or larvae occurred.

Cohorts were produced from the eggs of single females and pooled sperm from several males and reared separately to the pediveliger stage. Larvae from individual cohorts were held in $10 \mathrm{~L}$ buckets maintained at $25^{\circ} \mathrm{C}$ to $26^{\circ} \mathrm{C}$ in a water bath and reared on a mixed diet of cultured Isochrysis galbana, Chaetoceros neogracile, Pavlova pinguis, and Tetraselmis striata. All brood stock conditioning, larval rearing, and experiments were conducted in 20 psu seawater made by diluting near full strength sea water from Wachapreague Channel with filtered freshwater. Experiments were conducted using individual cohorts as replicates; however, the logistics of conditioning, spawning, and larval rearing precluded simultaneously running the experiments with more than one species or strain. Thus, the experiments were conducted sequentially the spring and summer of 2004-2006. Care was taken to conduct all experiments and larval rearing under identical conditions of diet, temperature, and salinity.

\section{Response to Substrate Type and Biofilms}

The effects of six substrates (three natural and three manmade), each with and without natural biofilms, on settlement were examined for each of the three oyster species/strains (Table 1). The natural substrates included $C$. virginica shell, $C$. ariakensis shell and granite. The oyster shell substrates were

TABLE 1.

Substrate selection experimental design, indicating the numbers of replicates trials using each species/stock of oyster larvae. $\mathrm{Cv}=$ Crassostrea virginica, $\mathrm{WCA}=$ west coast $C$ rassostrea ariakensis, SCA = south China Crassostrea ariakensis.

\begin{tabular}{lll}
\hline \hline \multicolumn{1}{c}{ Substrate } & \multicolumn{1}{c}{ No Biofilm } & \multicolumn{1}{c}{ Biofilm } \\
\hline C. virginica shell & Cv: 14 reps & Cv: 14 reps \\
& WCA: 17 reps & WCA: 17 reps \\
& SCA: 18 reps & SCA: 18 reps \\
C. ariakensis shell & Cv: 8 reps & Cv: 8 reps \\
& WCA: 12 reps & WCA: 12 reps \\
& SCA: 12 reps & SCA: 12 reps \\
Granite & Cv: 8 reps & Cv: 8 reps \\
& WCA: 12 reps & WCA: 12 reps \\
Fiberglass & SCA: 12 reps & SCA: 12 reps \\
& Cv: 14 reps & Cv: 14 reps \\
& WCA: 17 reps & WCA: 17 reps \\
PVC & SCA: 18 reps & SCA: 18 reps \\
& Cv: 8 reps & Cv: 8 reps \\
Wtainless steel & WCA: 12 reps & WCA: 12 reps \\
& SCA: 12 reps & SCA: 12 reps \\
& Cv: 8 reps & Cv: 8 reps \\
& WCA: 12 reps & WCA: 12 reps \\
& SCA: 12 reps & SCA: 12 reps \\
\hline
\end{tabular}


individual disarticulated valves of small $C$. virginica, WCA, or SCA. Shells were selected to have approximately the same surface area as the artificial substrates (see below). In trials with $C$. virginica larvae, conspecific shells, and those of WCA were used. In trials with larvae of either of the two $C$. ariakensis strains shells were used from the same strain as the larvae used in the treatment. All shells were cleaned of any tissue, thoroughly scrubbed, and air-dried prior to use. Granite pebbles with an upper surface area of approximately $5 \mathrm{~cm}^{2}$ were cleaned and air dried. The man-made substrates included stainless steel, polyvinyl chloride (PVC), and fiberglass. We used stainless washers with an upper surface area $=3 \mathrm{~cm}^{2}$; PVC and fiberglass were cut to the same dimensions as the washers. All substrate materials were thoroughly cleaned with freshwater and air dried before being used without biofilms or being subjected to biofilm development.

Natural biofilms were allowed to develop on one half of the substrates by soaking them for a minimum of $72 \mathrm{~h}$ in unfiltered flow-through seawater. The other half of the substrate replicates were maintained dry during this period and used as the No Biofilm treatment.

Individual pieces of a selected substrate type were added to small wells (measuring $4.2 \mathrm{~cm} \times 6 \mathrm{~cm} \times 4 \mathrm{~cm}$ deep) in a plastic (low density polyethylene) box such that each box contained one full set of test substrates at each biofouling level. Oyster shells were placed in the wells with the inside of the valve facing down. Because the curvature of the shells provided space for oyster larvae to have access to the undersides of the shells, we bent the stainless steel, PVC, and fiberglass rings slightly and placed them with the curved side down in the wells, thus allowing larvae access to both sides of these substrates. Fifty milliliters of filtered 20 psu seawater and approximately 50 oyster larvae were added with a pipette to each well, with each box receiving larvae from a single cohort. Boxes were placed in a water bath at $25^{\circ} \mathrm{C}$ to $26^{\circ} \mathrm{C}$ under ambient light and larvae were given $48 \mathrm{~h}$ to settle. At termination of the assays, the substrates and the walls of the wells were examined under a microscope and all oysters attached to the substrate or metamorphosed were counted as settled. For larvae settling onto the test substrates their position on the upper or lower surface of the substrate was recorded. Wells were rinsed with seawater and all unattached larvae, live and dead, were counted. Total larvae in each well was computed as the sum of settled (on the substrate and the box) and unattached (live and dead) larvae. The observed total numbers of larvae in each well $(\mathrm{X}=53.2, \mathrm{SD}=$ 12.9) were close to our nominal stocking density of 50 , but in calculating the proportion of larvae settling on the substrate, we used the observed total for each well.

Our initial experiments included all six substrates $\times$ two biofouling levels and eight replicate cohorts for $C$. virginica and 12 each of WCA and SCA. Because the data suggested a greater settlement by WCA than $C$. virginica onto fiberglass, we conducted additional trials using $C$. virginica shells and fiberglass at both biofilm levels with $2 C$. virginica cohorts, 5 WCA cohorts, and 6 SCA cohorts to increase statistical power for this comparison (see Table 1 for total replicate numbers at each treatment).

\section{Response to Sediment}

Similar assays as those described above were used to examine the impact of sedimentation on settlement. In this experiment three substrate treatments were used: (1) C. virginica shell with biofilm (as described above) and no sediment: Shell only treatment, (2) $C$. virginica shell with biofilm and sediment: Shell + Sediment treatment, and (3) Sediment only treatment. The sediment used in these experiments was obtained from an intertidal mudflat adjacent to the laboratory, sieved through a $100 \mu \mathrm{m}$-mesh screen and air dried. Treatment \#2 was constructed by placing a $C$. virginica shell with biofilm in one of the plastic wells with $50 \mathrm{~mL}$ of filtered 20 psu seawater, as described above, and gently pipetting a slurry with $\sim 1$ g dry weight of sediment onto the upper surface of the shell. This amount was sufficient to cover the shell with a fine layer of sediment. The Sediment only treatment was constructed by covering the bottom of the well with $\sim 1 \mathrm{~mm}$ depth of sediment. As in the previous experiment, approximately 50 larvae from either $C$. virginica, WCA, or SCA were added to each well in the plastic box, boxes were placed in a water bath and larvae given $48 \mathrm{~h}$ to settle. Experiments were conducted using larvae from single female cohorts for each species $(n=5$ for $C$. virginica and WCA; $n=11$ for SCA), and each treatment was replicated four times within each cohort. At termination the numbers of larvae attached to the substrate, attached to the walls of the wells and unattached were determined as described earlier.

\section{Response to Waterborne Chemical Cues}

To test for the effects of adult chemical signals that may induce settlement, and their specificity, bathwater solutions were prepared as described in detail by Tamburri et al. (1992). For these investigations, four types of solutions were made by bathing either 10 live: WCA (shell heights: $43-73 \mathrm{~mm}$ ), SCA (SH: 31-110 mm), C. virginica (SH: 66-140 mm), or hard clams Mercenaria. mercenaria (L.) (SH: 50-96), separately in individual $10 \mathrm{~L}$ containers of $1 \mu \mathrm{m}$-filtered, 20 psu seawater for eight hours, to allow for the natural release of metabolites. $C$. ariakensis bathwater was made using adults from the same stock (WCA or SCA) as the larvae in the trials and using WCA for the $C$. virginica trials. Bivalves were then removed, the water passed through a $1-\mu \mathrm{m}$ filter, and aliquots frozen until use. A control solution of $1 \mu \mathrm{m}$-filtered 20 psu seawater was frozen prior to use. Samples of each bathwater and control solution were analyzed for ammonium and total dissolved organic carbon concentrations (Table 2). Although the precise chemical cue(s) are not known, it has been found that signal production covaries with the release of these compounds by oysters (Tamburri et al. 1992, Zimmer-Faust \& Tamburri 1994).

Settlement responses to the bathwater and control solutions were examined using assays similar to those described earlier.

TABLE 2.

Ammonium and dissolved organic carbon (DOC) concentrations in bathwater and control solutions.

\begin{tabular}{lcc}
\hline \hline \multicolumn{1}{c}{ Solution } & $\mathbf{N H}_{\mathbf{4}}(\mathbf{m g} / \mathbf{L})$ & DOC $(\mathbf{m g} / \mathbf{L})$ \\
\hline C. virginica Bathwater & 0.45 & 24.03 \\
West Coast C. ariakensis Bathwater & 0.30 & 58.59 \\
South China C. ariakensis Bathwater & 0.31 & 34.05 \\
M. mercenaria Bathwater & 0.41 & 22.10 \\
Control (filtered bay water) & 0.18 & 5.00 \\
\hline
\end{tabular}


Pieces of either $C$. virginica shells with a biofilm or PVC without a biofilm (the most preferred and least preferred substrates, see Results) were placed in separate wells in replicate plastic boxes filled with one of the test solutions (Table 3). Approximately 50 larvae were then added to each box and the proportion of larvae that settled after $48 \mathrm{~h}$ determined. As before, larvae from separate single-female cohorts were used in replicate trials.

\section{Statistical Analyses}

Effects of oyster Species (=species or strain), Biofilm and Substrate on larval settlement were tested using the mixed models procedure in SAS (version 9). Mixed models analyses were selected because variances were heterogeneous even after applying standard transformations. Cohorts with $<20 \%$ settlement on fouled $C$. virginica shell were assumed to have low competency and omitted from the analyses. Data for the remaining cohorts were normalized as the proportion settled on substrate $\mathrm{X}$ divided by the proportion settled on fouled $C$. virginica shell to obtain a relative settlement index (RSI). This normalization was used to reduce the effect of variation among oyster types in absolute settlement rates on analyses of differences in the response of the three oyster types to substrates and other factors. Substrates with RSI $<1$ were less preferred than fouled native oyster; substrates with RSI $>1$ were more highly preferred. Because the RSI for fouled $C$. virginica shell had a variance of zero, $C$. virginica shell was not included as a substrate choice in these analyses, but the data are shown graphically for comparison.

The effects of oyster species, biofouling, and substrate type on RSI were analyzed as a repeated measures design where cohort was the primary experimental unit and the substrates within cohort were the subunits. Inspection of AIC results indicated that an unstructured covariance structure yielded a better model fit than variance groupings based on substrate type or the interactions between substrate and fouling. Preselected $a$ posteriori comparisons were conducted using sequential Bonferroni criteria for unequal variance $t$-tests of differences between least squares means. We present the results of main effects of fouling on substrate, as well as the interaction between

TABLE 3.

Adult chemical cue experimental design, indicating the number of replicate trials using each species/stock of oyster. $\mathrm{Cv}=$ Crassostrea virginica, $\mathrm{WCA}=$ west coast Crassostrea ariakensis, $\mathrm{SCA}=$ south China Crassostrea ariakensis.

\begin{tabular}{lll}
\hline \hline Bathwater & \multicolumn{1}{c}{ Cv-fouled } & \multicolumn{1}{c}{ PVC-clean } \\
\hline C. virginica & Cv: 8 reps & Cv: 8 reps \\
& WCA: 18 reps & WCA: 18 reps \\
& SCA: 14 reps & SCA: 14 reps \\
C. ariakensis & Cv: 8 reps & Cv: 8 reps \\
& WCA: 18 reps & WCA: 18 reps \\
SCA: 14 reps & SCA: 14 reps \\
& Cv: 8 reps & Cv: 8 reps \\
& WCA: 18 reps & WCA: 18 reps \\
Control & SCA: 14 reps & SCA: 14 reps \\
& Cv: 8 reps & Cv: 8 reps \\
& WCA: 18 reps & WCA: 18 reps \\
& SCA: 14 reps & SCA: 14 reps \\
\hline
\end{tabular}

substrate type and fouling. The most critical comparison, however, is the test for differences in settlement onto each substrate type between each of the $C$. ariakensis strains and $C$. virginica.

Because no larvae of either species settled in the Sediment only treatment, we analyzed the effects of Substrate (Shell only and Shell + sediment) and Species (C. virginica, SCA, WCA) on arcsin-square root transformed proportion of larvae settling on the substrate. We used a repeated measures mixed models analysis as described earlier. Inspection of AIC results and variances indicated that the homogeneous variance model best described the data once the Sediment only treatment was dropped.

The effects of waterborne chemical cues from adults on larval settlement were also analyzed using a repeated measures mixed model analysis and the arcsin-square root transformed proportion of larvae settling as the response variable. Inspection of AIC results for various covariance structures indicated that a model using variances grouped by the bathwater $\times$ substrate interaction without nonsignificant $(P>0.25)$ interaction terms provided the best fit. A posteriori comparisons of means were conducted using sequential Bonferonni criteria as mentioned earlier.

\section{RESULTS}

\section{Response to Substrate Type}

Fifteen cohorts ( $2 C v, 5$ SCA and 8 WCA) out of a total of 49 were rejected from the analyses because $<20 \%$ settlement was observed on the biofouled $C$. virginica shell treatment. Larval survival was high during the experiment and few dead larvae were observed. Settlement on the walls of the boxes was less than $1 \%(X=0.61 \%, S D=0.87 \%)$. Percent settlement on the treatment substrates ranged from $45.4 \%(\mathrm{SD}=28.0)$ for $C$. virginica larvae settling onto biofouled conspecific shells to $0 \%$ for $C$. virginica on the manmade substrates (Table 4).

The relative settlement index (RSI) was affected by $S u b$ strate, Biofilm, the interaction between the two, and the interaction between Species and Substrate (Fig. 1, Table 5). Because the significant 3-way interaction, required that we compare differences among species in relative settlement rates on the various substrates separately for fouled and unfouled substrates, we considered the Species $\times$ Substrate interaction only for fouled surfaces - the comparisons most relevant to field conditions.

Settlement was greatest on oyster shell, from both species, and next highest on granite. Little settlement was observed on the artificial substrates, though $C$. ariakensis exhibited a greater propensity to settle on fiberglass than did C. virginica (Fig. 1). Natural biofilms enhanced settlement response in both oyster species.

A posteriori least squares means comparisons indicated that RSI onto $C$. ariakensis shell was similar to that onto granite $(P$ $=0.04$, but nonsignificant because of the number of a posteriori comparisons), but significantly higher than that on fiberglass, PVC, or steel (all $P<0.0009$ ); settlement onto PVC and steel did not significantly differ (all $P=0.76$ ). Settlement was also higher on fouled than on clean substrates (Table 5). The effect of fouling varied among substrates, however. Fouling significantly increased settlement onto $C$. ariakensis shells and granite $(P=$ 0.0012 and $P<0001$, respectively), had a marginal, but nonsignificant effect on settlement onto fiberglass $(P=0.021)$, and did not affect settlement onto PVC $(P=0.41)$ or steel $(P=$ $0.27)$. 
TABLE 4.

Mean (SD) percent settlement for each oyster species on each substrate by biofouling level. Percent settlement calculated using the observed total number of larvae in each well (see text for explanation) and the number of oysters settled on both upper and lower surfaces of the substrate. See text for explanation of species abbreviations.

\begin{tabular}{clcc}
\hline \hline & & \multicolumn{2}{c}{$\%$ Settled on Substrate } \\
\cline { 3 - 4 } Larval Species & Substrate & Clean & Biofouled \\
\hline SCA & CV-shell & $3.7(8.3)$ & $19.3(18.4)$ \\
SCA & CA-shell & $4.0(5.0)$ & $16.7(17.0)$ \\
SCA & Granite & $1.4(3.0)$ & $7.1(11.0)$ \\
SCA & PVC & $0.1(0.4)$ & $0.6(1.6)$ \\
SCA & Fiberglass & $0.2(4.6)$ & $4.4(6.1)$ \\
SCA & Steel & $0.1(0.5)$ & $0.4(0.9)$ \\
WCA & CV-shell & $20.7(25.3)$ & $33.0(22.2)$ \\
WCA & CA-shell & $13.2(22.8)$ & $34.8(19.0)$ \\
WCA & Granite & $2.6(6.3)$ & $14.3(19.1)$ \\
WCA & PVC & $0.6(0.9)$ & $1.9(3.13)$ \\
WCA & Fiberglass & $3.0(4.1)$ & $9.2(15.9)$ \\
WCA & Steel & $0.3(0.8)$ & $0.2(0.6)$ \\
CV & CV-shell & $5.8(13.5)$ & $45.4(28.0)$ \\
CV & CA-shell & $10.5(16.8)$ & $41.3(28.3)$ \\
CV & Granite & $1.4(3.1)$ & $35.5(23.7)$ \\
CV & PVC & $0(0)$ & $0(0)$ \\
CV & Fiberglass & $0(0)$ & $0(0)$ \\
CV & Steel & $0(0)$ & $0(0)$ \\
\hline
\end{tabular}

There were no significant differences among the three oyster types tested in their relative settlement on the various substrates tested $(P>0.05)$ with two exceptions. Both SCA $(P=0.0049)$ and WCA larvae $(P<0.0001)$ had a greater tendency to settle on fouled fiberglass than did $C$. virginica larvae. In addition, there was a nonsignificant trend toward higher RSI on fouled $C$. ariakensis shell by SCA than by WCA $(P=0.035)$.

\section{Response to Sediment}

No oysters of either species were observed to attach directly to the sediment in the Sediment only treatment (Fig. 2). Mean percent settlement did not differ between the remaining substrates (Shell only and Shell + Sediment), or the interaction between species and substrate (Table 6). Most oysters were observed to settle onto the underside of shells, which likely contributed to the lack of observed difference between the Shell only and Shell + Sediment treatments. In the few instances in which oysters were observed to settle on the upper surface of the Shell + Sediment treatment, close visual inspection of the shells revealed that these oysters had settled on areas of the shell that were locally devoid of sediment. The significant effects of species on settlement reflect slightly higher overall settlement by WCA than by SCA.

\section{Response to Waterborne Chemical Cues}

Proportion of larvae settling within chambers ranged from 0.60 for settlement in the presence of biofouled $C$. virginica shell in C. ariakensis bathwater to 0.01 for settlement onto clean PVC in $M$. mercenaria and control bathwaters for all species combined (Fig. 3). The mixed model analysis revealed signifi-
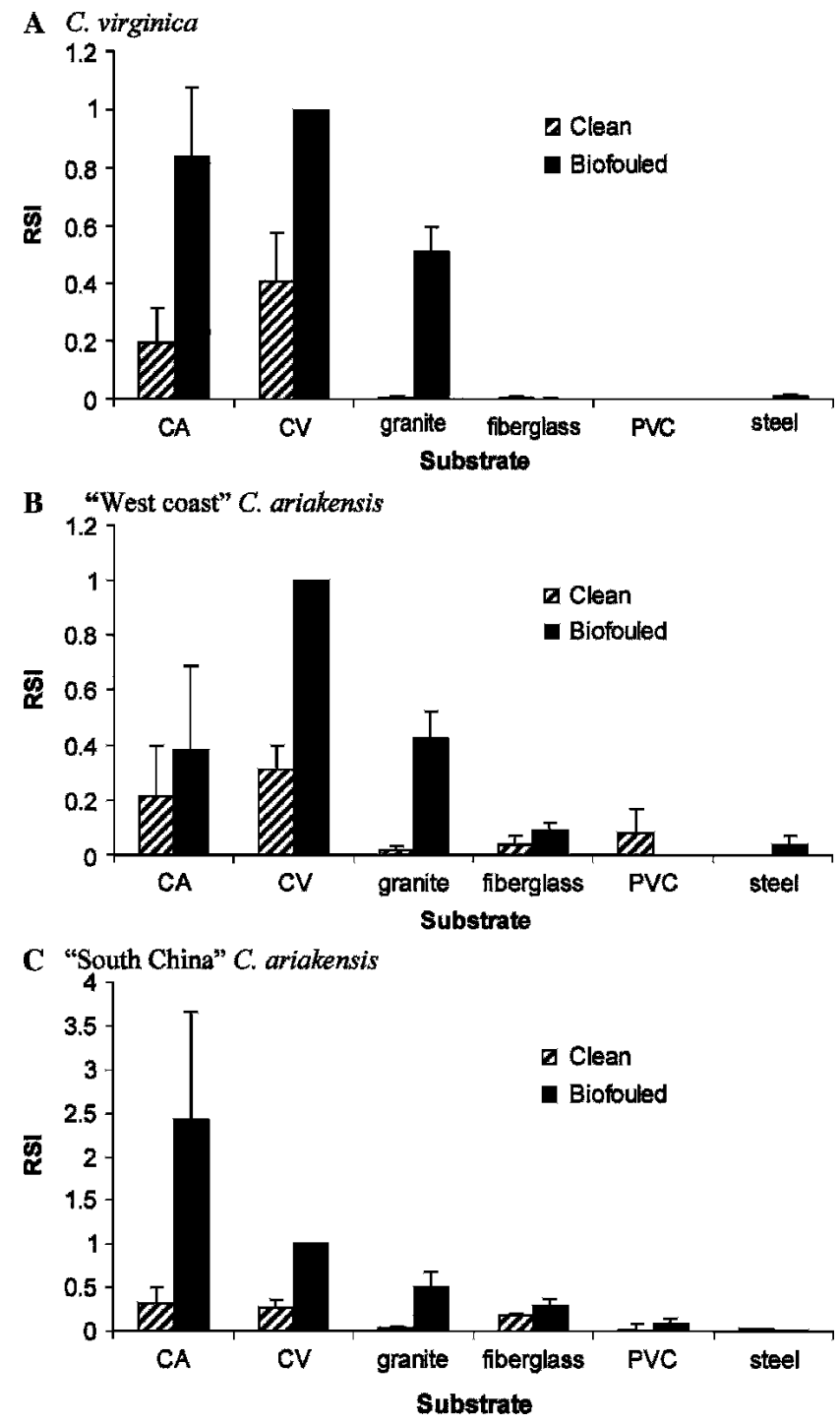

Figure 1. Mean (+SE) Relative Settlement Index (RSI) for each substrate and biofouling level for (A) Crassostrea virginica, (B) "West Coast" Crassostrea ariakensis and (C) "South China" C. ariakensis. Bars are one standard error above the means.

cant main effects for Substrate and Bathwater, but no differences between Species (Table 7). The Substrate effect is a reflection of overall low settlement onto clean PVC. Our results for settlement onto substrates also indicate a significant Species $\times$ Substrate interaction reflecting a significantly stronger affinity for settlement on fouled shell by $C$. virginica larvae than by SCA or WCA larvae (a posteriori ls means $P<0.005$ for both comparisons). A posteriori comparisons considering total settlement into chambers, not only settlement onto substrates, indicate significantly higher settlement in the Crassostrea bathwater treatments than in the Control and Mercenaria treatments $(\mathrm{CV}=\mathrm{CA}>\mathrm{Control}=\mathrm{MM})$.

\section{DISCUSSION}

To determine if the introduction of Asian oyster, C. ariakensis, into the Chesapeake Bay can result in self-sustaining populations that replace a productive fishery and important 
TABLE 5.

Mixed Models analysis of the effects of Species, Substrate and Biofilm on Relative Settlement Index (RSI).

\begin{tabular}{llrr}
\hline \hline \multicolumn{1}{c}{ Source } & \multicolumn{1}{c}{ df } & \multicolumn{1}{c}{ F } & \multicolumn{1}{c}{$\boldsymbol{P}$} \\
\hline Species & $2 / 19.6$ & 3.44 & 0.0524 \\
Substrate & $4 / 19.8$ & 19.30 & $<0.0001$ \\
Biofilm & $1 / 28$ & 63.10 & $<0.0001$ \\
Substrate x Biofilms & $4 / 24$ & 12.53 & $<0.0001$ \\
Species x Substrate & $8 / 20.8$ & 3.31 & 0.0134 \\
Species x Biofilms & $2 / 27.3$ & 0.25 & 0.7783 \\
Species x Substrate x & $8 / 20.8$ & 2.53 & 0.0315 \\
Biofilms & & & \\
\hline
\end{tabular}

ecosystem services previously provided by $C$. virginica, a basic understanding of similarities and differences in larval settlement responses between the two species is required. Our results demonstrate that there are many similarities in the larval settlement between $C$. virginica and the south China and west coast strains of $C$. ariakensis but also perhaps important differences.

Overall settlement rates in our experiments were lower for $C$. ariakensis than for $C$. virginica. However, this likely reflects a reduced ability on our part to determine competency in $C$. ariakensis larvae, because it has a less distinctive eyespot than competent $C$. virginica larvae. Thus, we advise caution in interpreting absolute settlement rates as reported in Table 4.

All species and strains tested preferred shell as a settlement substrate, and exhibited greatest settlement on solid, natural substrates covered with biofilms. However, our results indicate a potentially important difference between $C$. virginica and $C$. ariakensis. Both strains of $C$. ariakensis had significantly higher preferences for settlement onto fiberglass than did $C$. virginica. Whereas in nature, $C$. virginica has been found on several manmade substrates (Kennedy 1996; personal observations) and would appear to eventually colonize fiberglass to some extent as selectivity decreases with larval age, our direct comparison suggests that $C$. ariakensis may be more likely to attach to fiberglass in the wild. Crassostrea ariakensis might therefore pose a greater risk of becoming a fouling nuisance species.

The enhancement of larval settlement by natural biofilms growing on hard substrates has been demonstrated for many invertebrate species (Pawlik 1992), including C. virginica and

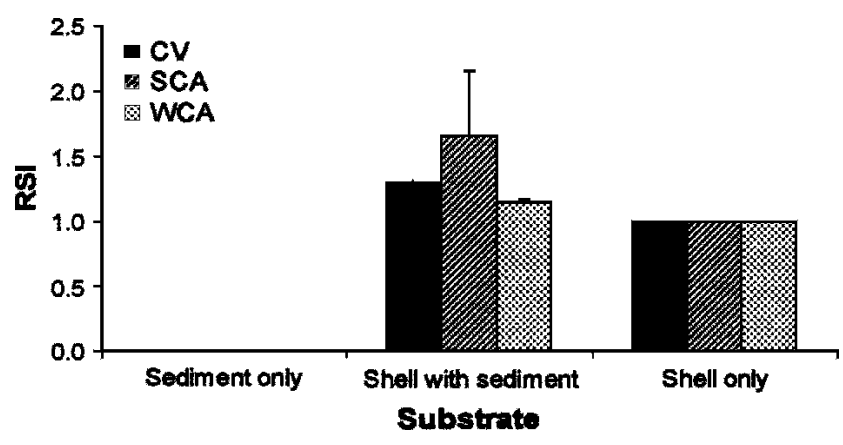

Figure 2. Mean (+SE) Relative Settlement Index (RSI) by oyster species onto the sediment treatments.
TABLE 6.

Mixed models analysis for the effects of Species and Substrate (Shell only and Shell + sediment) on mean percent settlement.

\begin{tabular}{lccc}
\hline \hline \multicolumn{1}{c}{ Source } & df & F & $\boldsymbol{P}$ \\
\hline Species & $2 / 162$ & 3.13 & 0.046 \\
Substrate & $1 / 162$ & 1.98 & 0.161 \\
Species x Substrate & $2 / 162$ & 1.50 & 0.225 \\
\hline
\end{tabular}

C. gigas (e.g., Veitch \& Hidu 1971, Fitt et al. 1989). Although we did not quantify or taxonomically characterize the biofilms present in our experimental treatments, the conditions in all assays were essentially identical, and the results demonstrate clearly that the presence of some biofilm growth greatly increase larval settlement of the south China and west coast strains of $C$. ariakensis when compared with clean substrates. Therefore, like C. virginica, a species introduction plan that utilizes oyster shell material with natural biofilms as initial bed or reef material for C. ariakensis will likely enhance larval recruitment.

Assays examining the impacts of sediment on settlement demonstrated that, like C. virginica (Bahr 1976, Seliger \& Boggs 1988), the larvae of both strains of $C$. ariakensis require exposed clean substrates for colonization. All larvae tested either avoided or failed to settle directly on soft sediment and on sediment-covered shells, attaching only to small clean areas on the upper surface or to the clean undersurfaces of shells. Therefore, the problems associated with high sediment loads and excessive siltation in the Chesapeake Bay that impairs habitat quantity and quality for $C$. virginica larval settlement will also be a limiting factor in successful recruitment for both strains $C$. ariakensis.

Chemical cues have also long been known to mediate larval settlement for a variety of aquatic invertebrates (Pawlik 1992). In fact, the larvae of $C$. virginica and $C$. gigas have been shown to alter their behavior in the water column in response chemical cues emitted from adult conspecifics (Tamburri et al. 1992, Turner et al. 1994, Zimmer-Faust \& Tamburri 1994, Tamburri et al. 2007). However, whereas this previous work with oyster larvae demonstrated significant changes in larval behavior prior to attachment, enhanced metamorphosis in response to dissolved cues was never found. Surprisingly, we found significant increases in the proportion of larvae that attached to surfaces when compounds emitted by oysters are present in the water,

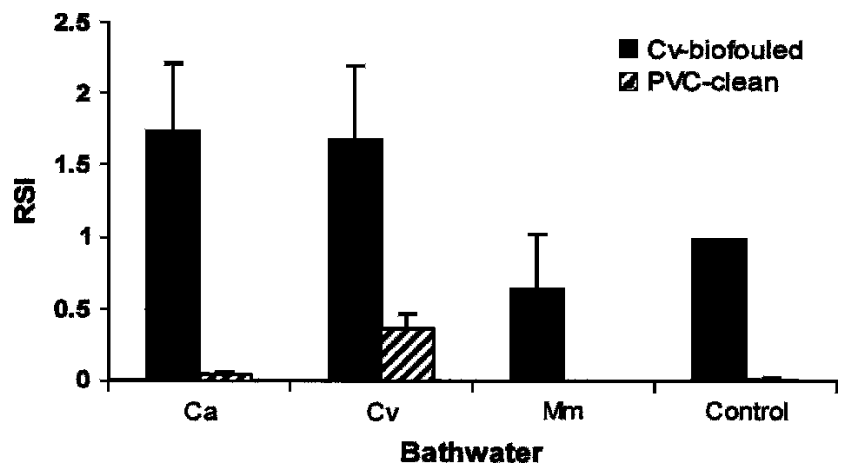

Figure 3. Mean (+SE) Relative Settlement Index (RSI) for all oyster species combined in each bathwater treatment by substrate type. 
TABLE 7.

Mixed models analysis for the effects of Species, Substrate and Bathwater on the proportion of larvae settling onto test substrates. A significant bathwater effect $(P<0.001)$ was also found for total settlement in experimental chambers, which is a more relevant test for the influence of bathwater. Results reflect model runs without interaction terms with $P>0.25$ in the full model. The three-way interaction, species $\times$ bathwater and bathwater $\times$ substrate terms were dropped for both response variables considered (settlement onto substrates and total settlement into chamber).

\begin{tabular}{lrrr}
\hline \hline \multicolumn{1}{c}{ Source } & df & \multicolumn{1}{c}{ F } & \multicolumn{1}{c}{$\boldsymbol{P}$} \\
\hline Species & $2 / 74.2$ & 7.79 & 0.0008 \\
Bathwater & $3 / 33.3$ & 5.92 & 0.0024 \\
Substrate & $1 / 85.7$ & 206.51 & $<0.0001$ \\
Species x Substrate & $2 / 74.2$ & 6.62 & 0.0023 \\
\hline
\end{tabular}

especially if all settled larvae are considered including those attached to the walls of the plastic settlement chamber.

Our results also indicate that the waterborne chemical cues mediating oyster larval settlement are not species-specific. We found that dissolved compounds emitted from either oyster species/strain (congeneric) were as powerful as chemical signals from adults of the same species (i.e., $C$. virginica and $C$. ariakensis larvae settled similarly in response conspecific and congeneric cues). A comparable lack of chemical cue specificity has been demonstrated for C. virginica and C. gigas (Tamburri et al. 1992, Turner et al. 1994, Zimmer-Faust \& Tamburri 1994,
Tamburri et al. 2007). Because there are no obvious speciesspecific responses, gregarious settlement onto multigenerational and multispecies reefs may eventually occur if $C$. ariakensis is introduced into the Chesapeake Bay. Such a scenario raises important questions regarding the impacts of oyster cohabitation and interspecific competition.

Overall, our results demonstrate that like $C$. virginica, both strains of $C$. ariakensis use a variety of physical and chemical cues when selecting a site for colonization and that many of their responses mirror those of the native oyster species. This is not surprising, given similarities in larval behavior and settlement found previous between $C$. virginica and $C$. gigas. However, the question still remains about how these similarities and subtle differences will ultimately translate into the probability of a successful introduction and risks to native oysters. Whereas our results provide some evidence that $C$. ariakensis may be able to establish naturalized, reproducing, and selfsustaining populations in the Chesapeake Bay, much more information is required on other aspects of the biology, ecology, and physiology of this species to predict the ecosystem-level consequences of the proposed introduction.

\section{ACKNOWLEDGMENTS}

The authors thank the NOAA Chesapeake Bay Office (NOAA Grant \# NA04NMF4570420) and the Maryland Department of Natural Resources for supporting this work. The authors also thank Rochell Brown, Susan Spears, and Lynn Walker for their help culturing larvae and conducting experiments. Elgin Perry provided statistical advice.

\section{LITERATURE CITED}

Bahr, L. M. 1976. Energetic aspects of the intertidal oyster reef community at Sapelo Island, Georgia. Ecology 57:121-131.

Bayne, B. L. 1969. The gregarious behaviour of the larvae of Ostrea edulis L. at settlement. J. Mar. Biol. Assoc. UK. 49:327356.

Breese, W. P. \& R. E. Malouf. 1977. Hatchery rearing techniques for Crassostrea rivularis. Aquaculture 12:123-126.

Buss, L. W. 1981. Group living, competition, and the evolution of cooperation in a sessile invertebrate. Science 213:1012-1014.

Coen, L. D. \& M. W. Luckenbach. 2000. Developing success criteria and goals for evaluating shellfish habitat restoration: Ecological function or resource exploitation? Ecol. Eng. 15:323-343.

Denny, M. W. \& M. Shibata. 1989. Consequences of surf-zone turbulence for settlement and external fertilization. Am. Nat. 134:859-889.

Fitt, W. K., M. P. Labare, W. C. Fuqua, M. Walch, S. L. Coon, D. B. Bonar, R. R. Colwell \& R. M. Weiner. 1989. Factors influencing bacterial production of inducers of settlement behavior of larvae of the oyster Crassostrea gigas. Microb. Ecol. 17:287-298.

Ford, S. E. \& K. A. Ashton-Alcox. 1998. MSX-A review and update. J. Shellfish Res. 17:353-354.

Hidu, H. 1969. Gregarious setting in the American oyster Crassostrea virginica (Gmelin). Chesapeake Sci. 10:85-92.

Homer, M. L., M. Tarnowski \& L. Baylis. 1996. Eastern oyster stock assessment in Maryland. J. Shellfish Res. 15:521-522.

Highsmith, R. C. 1982. Induced settlement and metamorphosis of a sand dollar (Dendraster excentricus) larvae in predator-free sites: adult sand dollar beds. Ecology 63:329-337.

Kennedy, V. S. 1996. Biology of Larvae and Spat. In: V. S. Kennedy, R. I. E. Newell \& A. Eble, editors. The eastern oyster, Crassostrea virginica. College Park, MD: Maryland Sea Grant Publication UMSG-TS-96-01. pp. 371-421.

Kent, F. G. 1988. Making dead oysters talk: Techniques for analyzing oysters from archeological sites. Maryland Historical Trust, Crownsville, MD: Jefferson Paterson Park and Museum Report.

Kirby, M. X. \& H. M. Miller. 2005. Response of a benthic suspension feeder (Crassostrea virginica Gmelin) to three centuries of anthropogenic eutrophication in Chesapeake Bay. Estuar. Coast. Shelf Sci. 62:679-689.

Lenihan, H. S. \& J. H. Grabowski. 1998. Recruitment to and utilization of oyster reef habitat by fishes, shrimps, and blue crabs: an experiment with economic analysis. Beaufort, N.C.: National Marine Fisheries Service, National Research Council Final Report No. 197.

Levitan, D. R. 1991. Influence of body size and population density on fertilization success and reproductive output in a free-spawning invertebrate. Biol. Bull. 181:261-268.

MacKenzie, C. L. \& V. G. Burrell, Jr. 1997. Trends and status of molluscan fisheries in North and Central America and Europe - a synopsis. In: The history, present condition, and future of molluscan fisheries of North and Central America and Europe, Vol. 1. Atlantic and Gulf Coasts. Washington, DC: US Department of Commerce, NOAA Technical Report 127, pp. 1-14.

National Research Council. 2004. Non-native oysters in Chesapeake Bay. National Academies Press. Washington, DC. 325 pp.

Newell, R. I. E. 1988. Ecological changes in Chesapeake Bay: are they the result of overharvesting the American oyster (Crassostrea virginica)? In: M. Lynch \& E. C. Krome, editors. Understanding the estuary: advances in Chesapeake Bay Research. Gloucester 
Point, VA: Chesapeake Research Consortium Publication 129. pp. 536-546.

Olafsson, E. B., C. H. Peterson \& W. G. Ambrose, Jr. 1994. Does recruitment limitation structure populations and communities of macro-invertebrates in marine soft sediments: The relative significance of pre- and post-settlement processes. Oceanogr. Mar. Biol. Ann. Rev. 32:65-109.

Palmer, M. A., J. D. Allan \& C. A. Butman. 1996. Dispersal as a regional process affecting the local dynamics of marine and stream benthic invertebrates. Trends Evol. Ecol. 11:322-326.

Pawlik, J. R. 1992. Chemical ecology of the settlement of benthic marine invertebrates. Oceanogr. Mar. Biol. Ann. Rev. 30:273-335.

Pennington, J. T. 1985. The ecology of fertilization of echinoid eggs: The consequences of sperm dilution, adult aggregation, and synchronous spawning. Biol. Bull. 169:417-430.

Rothlisberg, P. C. \& J. A. Church. 1994. Processes controlling the larval dispersal and postlarval recruitment of Penaeid prawns. In: P. W. Sammarco \& M. L. Heron, editors. Coastal and estuarine studies. Washington, DC: American Geophysical Union. pp. 235-252.

Roughgarden, J., J. T. Pennington, D. Stoner, S. Alexander \& K. Miller. 1991. Collisions of upwelling fronts with the intertidal zone: The cause of recruitment pulses in barnacle populations of central California. [USA]. Acta. Oecologica. 12:35-52.

Sebens, K. P. 1983. Larval and juvenile ecology of the temperate octocoral Alcyonium siderium Verrill II. Fecundity, survivorship, and juvenile growth. J. Exp. Mar. Biol. Ecol. 72:263-285.

Seliger, H. H. \& H. Boggs. 1988. Long-term patterns of anoxia in the Chesapeake Bay. In: M. Lynch \& E. C. Krone, editors. Under- standing the estuary: advances in Chesapeake Bay research. Solomons, MD: Chesapeake Research Consortium, Publ. 129. pp. 570583.

Scientific and Technical Advisory Committee (STAC). 2004. Identifying and prioritizing research required to evaluate ecological risks and benefits of introducing diploid Crassostrea ariakensis to restore oysters to Chesapeake. Edgewater, MD: NOAA Chesapeake Bay Program (http://www.chesapeake.org/stac/Pubs/STACCariakensis ReportFormal.pdf).

Tamburri, M. N., R. K. Zimmer-Faust \& M. L. Tamplin. 1992. Natural sources and properties of chemical inducers mediating settlement of oyster larvae: A re-examination. Biol. Bull. 183:327-338.

Tamburri, M. N., C. M. Finelli, D. S. Wethey \& R. K. Zimmer-Faust. 1996. Chemically mediated larval settlement behavior in flow. Biol. Bull. 191:367-373.

Tamburri, M. N., R. K. Zimmer \& C. A. Zimmer. 2007. Mechanisms reconciling gregarious larval settlement with adult cannibalism. Ecol. Mono. 72:255-268.

Turner, E. J., R. K. Zimmer-Faust, M. A. Palmer \& M. Luckenbach. 1994. Settlement of oyster (Crassostrea virginica) larvae: Effects of water flow and a water-soluble chemical cue. Limnol. Oceanogr. 39:1579-1593.

Veitch, F. P. \& H. Hidu. 1971. Gregarious setting in the American oyster Crassostrea virginica Gmelin: I. Properties of a partially purified "setting factor.". Chesapeake Sci. 12:173-178.

Zimmer-Faust, R. K. \& M. N. Tamburri. 1994. Chemical identity and ecological implications of a waterborne larval settlement cue. Limnol. Oceanogr. 39:1075-1087. 